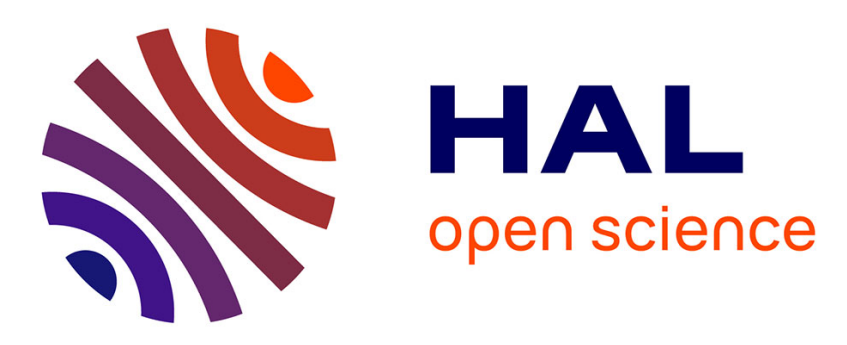

\title{
Design and characterization of red fluorogenic push-pull chromophores holding great potential for bioimaging and biosensing
}

Chenge Li, Marie-Aude Plamont, Isabelle Aujard, Thomas Le Saux, Ludovic Jullien, Arnaud Gautier

\section{To cite this version:}

Chenge Li, Marie-Aude Plamont, Isabelle Aujard, Thomas Le Saux, Ludovic Jullien, et al.. Design and characterization of red fluorogenic push-pull chromophores holding great potential for bioimaging and biosensing. Organic \& Biomolecular Chemistry, 2016, 14, pp.9253-9261. 10.1039/C6OB01612J . hal-01366661

\section{HAL Id: hal-01366661 \\ https: / hal.sorbonne-universite.fr/hal-01366661}

Submitted on 15 Sep 2016

HAL is a multi-disciplinary open access archive for the deposit and dissemination of scientific research documents, whether they are published or not. The documents may come from teaching and research institutions in France or abroad, or from public or private research centers.
L'archive ouverte pluridisciplinaire HAL, est destinée au dépôt et à la diffusion de documents scientifiques de niveau recherche, publiés ou non, émanant des établissements d'enseignement et de recherche français ou étrangers, des laboratoires publics ou privés. 


\title{
Journal Name
}

\section{Design and characterization of red fluorogenic push-pull chromophores holding great potential for bioimaging and biosensing}

\author{
Chenge $\mathrm{Li}^{\mathrm{a}, \mathrm{b}}$, Marie-Aude Plamont ${ }^{\mathrm{a}, \mathrm{b}}$, Isabelle Aujard ${ }^{\mathrm{a}, \mathrm{b}}$, Thomas Le Saux ${ }^{\mathrm{a}, \mathrm{b}}$, Ludovic Jullien ${ }^{\mathrm{a}, \mathrm{b},{ }^{*}}$ and \\ Arnaud Gautier ${ }^{\mathrm{a}, \mathrm{b}, *}$

\begin{abstract}
Fluorogenic chromophores have been used recently for fluorescence reporting and biosensing. Their ability to turn on upon specific interaction with a given target has been exploited in particular for the design of fluorogen-based reporters enabling biomolecule labeling and imaging. In this paper, we report the development and exhaustive characterization of a new family of red fluorogenic push-pull chromophores, holding great potential for the development of fluorogen-based reporters or intracellular fluorogenic markers. The proposed methodology is generic and should find general applicability
\end{abstract} \\ in the discovery of new fluorogenic dyes suitable for the design of fluorogen-based reporters and biosensors.
}

\section{Introduction}

Chemical Biology aims at discovering powerful molecules to address biological problems that would otherwise remain elusive. The development of chemical biology tools to observe or manipulate biological processes often needs the pairing of tailor-made synthetic molecules with engineered genetically encodable biomolecules in order to obtain selective and controlled output functions. The developments of advanced biomolecular labeling tools - composed of genetically targetable tags engineered to specifically interact with synthetic functional ligands - nicely illustrate the power of hybridizing synthetic and genetically encodable molecules ${ }^{1-3}$.

In the context of fluorescence labeling, turn-on systems exploiting fluorogenic compounds (so-called fluorogens) have recently gained popularity. The use of fluorogenic dyes - that light up when they interact with their complementary target easily provides high contrast without the need for washing dye excess $^{4,5}$. In addition, the requirement for fluorogen supply opens great opportunities for on-demand applications where the fluorescence is desired only at a given time or at a given density.

One of the current limitations in the development of efficient fluorogen-based reporters is the small number of fluorogenic compounds eligible for their design ${ }^{5}$. The exploration and discovery of new families of fluorogenic dyes

\footnotetext{
a. École Normale Supérieure, PSL Research University, UPMC Univ Paris 06, CNRS, Département de Chimie, PASTEUR, 24 rue Lhomond, 75005 Paris, France.

${ }^{b .}$ Sorbonne Universités, UPMC Univ Paris 06, ENS, CNRS, PASTEUR, 75005 Paris, France.

* Correspondence should be addressed to: ludovic.jullien@ens.fr and arnaud.gautier@ens.fr
}

is thus indispensable. In this context, several spectroscopic changes have been envisioned to generate a fluorogenic effect upon biomolecular interactions ${ }^{4,5}$. Given that brightness is a convolution of fluorescence quantum yield and absorption coefficient, any changes of one of these two parameters upon target binding can give a fluorogenic behavior. The fluorescence quantum yield of some dyes can increase upon motion restriction. These dyes do not fluoresce when free in solution because they deexcite from the excited state mainly through non-radiative processes involving internal molecular motions; however, when they are immobilized inside a complementary cavity, these non-radiative processes are impaired and fluorescence becomes the main relaxation pathway, which gives rise to very bright complexes. Examples of such fluorogens are (i) DAPI or Hoechst dyes used to stain DNA, (ii) thiazole orange and malachite green used to label proteins fused to fluorogen-activating proteins (FAPs) $)^{6-9}$, (iii) the chromophore of the green fluorescent protein (GFP) and its analogs used for the development of RNA mimics of GFP ${ }^{10-}$ 14 , or (iv) merocyanines used to label CRABPII ${ }^{15}$. Increase in fluorescence quantum yield can also be induced by polarity changes as in the case of 7-dimethylaminocoumarin derivatives that are specifically activated within non-polar environments. This behavior has been used for instance to design fluorogenic substrates for the specific covalent labeling of PYP-tag ${ }^{16}$. A second way to obtain a fluorogenic effect is to play with the absorption coefficient. Far-red fluorescent silicon-rhodamines display for instance fluorogenic behaviour because of their polarity-dependent interconversion between a spiro closed form with low absorbance at $650 \mathrm{~nm}$ and a zwitterionnic opened form strongly absorbing at $650 \mathrm{~nm}^{17}$. Switching from the non-absorbing to the absorbing form activates thus fluorescence. This singular behavior was used to 
a

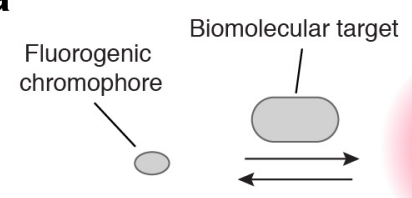

Fluorescence OFF
Fluorescence ON b<smiles>[2H]c1ccc(/C=C/C=c2/c(=O)[nH]/c(=C\C=C\c3cc(/C=C/C=C4\NC(=O)NC4=O)ccc3[2H])n2C(=O)O)cc1</smiles>

Absorption red shift

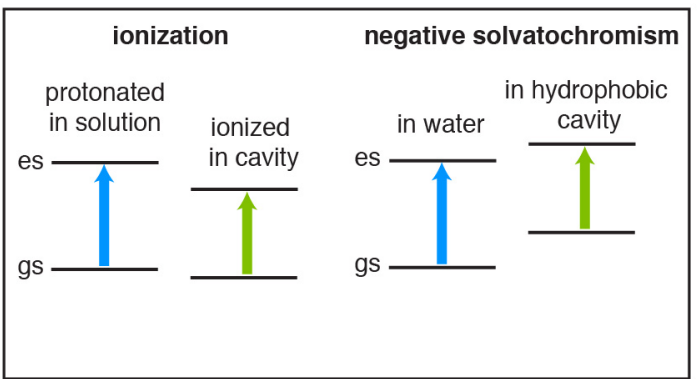

Figure 1. Red fluorogenic chromophores for reporting and biosensing. (a) General fluorogen activation principle. (b) Chemical structures of the red fluorogenic compounds 1a-d and 2a-d developed in this study. (c) Highly specific fluorogen activation upon binding in a complementary biomolecular cavity can result from the combination of various spectroscopic changes such as fluorescence quantum yield increase (through motion restriction) and absorption red shift (through specific ionization or polarity change).

a

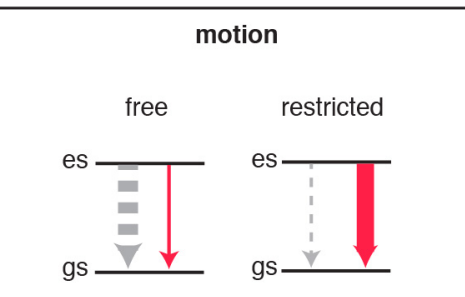

radiationless deexcitation $\quad 1= \pm \pm \|$ radiative deexcitation

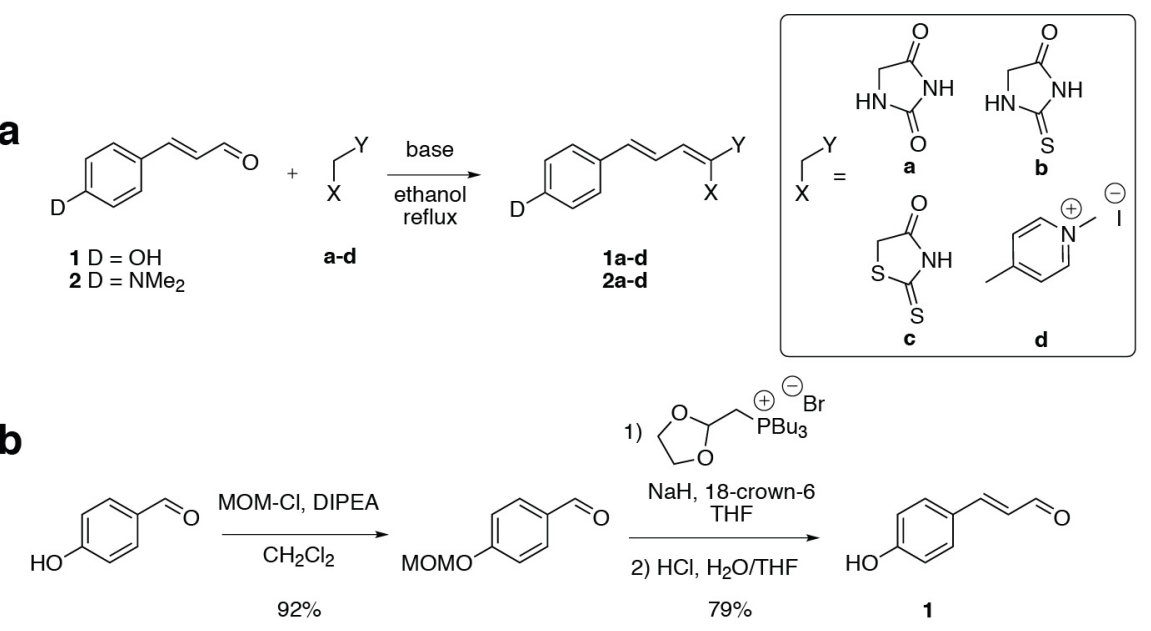

Figure 2. Chemical synthesis. (a) General strategy for the syntheses of 1a-d and 2a-d. (b) Synthesis of aldehyde 1.

develop fluorogenic probes for the covalent labeling of SNAPtag/CLIP-tag/Halo-tag ${ }^{17}$ and for fluorescence imaging of actin and tubulin in living cells ${ }^{18}$. A change in absorption coefficient at a given wavelength can also result from a chromophore absorption shift induced by a change of environment. Fluorogenic labeling can hence be obtained using solvatochromic dyes displaying large changes in maximal absorption wavelength upon binding hydrophobic biomolecular cavities. Alternatively, absorption shift can also result from ionization of an auxochromic group. This spectroscopic change has been recently coupled with bindinginduced fluorescence quantum yield increase to design a highly specific fluorogen-based reporter called Y-FAST (Yellow Fluorescence-Activating and Absorption-Shifting Tag) ${ }^{19}$, which relies on the reversible non-covalent binding of 4- hydroxybenzylidene rhodanine (HBR) or 4-hydroxy-3-methylbenzylidene rhodanine (HMBR). HBR and HMBR are nonfluorescent in solution but strongly fluoresce yellow light when immobilized within Y-FAST, a small protein of $14 \mathrm{kDa}$ engineered from the photoactive yellow protein (PYP); in addition, HBR and HMBR are protonated in solution because of a high $\mathrm{p} K_{\mathrm{A}}$, but are deprotonated within Y-FAST, leading to a 80 $\mathrm{nm}$ red-shift in absorption (because of the stronger electrondonation of the phenolate). This second spectroscopic modification enables to further increase the fluorogenic effect by choosing the excitation wavelength so that free or nonspecifically bound fluorogen does not contribute to the fluorescence signal, ensuring hence high imaging contrast.

In order to extend the collection of Fluorescence-Activating and absorption-Shifting Tags (FAST) and obtain a palette of 
Table 1. Physicochemical properties of compounds $1 \mathrm{a}-\mathrm{d}$ at $\mathrm{pH} 6$ and $\mathrm{pH} 10$ ( $\pm 40 \%$ Glycerol). Abbreviations are as follows: $\mathrm{p} K_{\mathrm{A}}$, acidity constant; $\lambda_{\mathrm{abs}}$, wavelength of maximal absorption; $\lambda_{\text {em }}$, wavelength of maximal emission; $\varepsilon$, molar absorption coefficient at $\lambda_{\mathrm{abs}} ; \phi$, fluorescence quantum yield.

\begin{tabular}{|c|c|c|c|c|c|c|c|}
\hline & \multirow[b]{2}{*}{$\mathrm{p} K_{\mathrm{A}}$} & \multicolumn{2}{|c|}{ pH 6} & \multicolumn{2}{|c|}{ pH 10} & \multicolumn{2}{|c|}{ pH $10+40 \%$ Glycerol } \\
\hline & & $\begin{array}{c}\lambda_{\mathrm{abs}}[\varepsilon] \\
{[\mathrm{nm}]\left[\mathrm{mM}^{-1} \cdot \mathrm{cm}^{-1}\right]}\end{array}$ & $\begin{array}{c}\lambda_{\mathrm{em}}[\phi] \\
{[\mathrm{nm}][\%]}\end{array}$ & $\begin{array}{c}\lambda_{\mathrm{abs}}[\varepsilon] \\
{[\mathrm{nm}]\left[\mathrm{mM}^{-1} \cdot \mathrm{cm}^{-1}\right]}\end{array}$ & $\begin{array}{c}\lambda_{\mathrm{em}}[\phi] \\
{[\mathrm{nm}][\%]}\end{array}$ & $\begin{array}{c}\lambda_{\mathrm{abs}}[\varepsilon] \\
{[\mathrm{nm}]\left[\mathrm{mM}^{-1} \cdot \mathrm{cm}^{-1}\right]}\end{array}$ & $\begin{array}{c}\lambda_{\text {em }}[\phi] \\
{[\mathrm{nm}][\%]}\end{array}$ \\
\hline 1a & 8.9 & $370[40]$ & $520[0.4]$ & $394[32]$ & $590[0.5]$ & $396[31]$ & $595[1.0]$ \\
\hline $1 b$ & 8.9 & 415 [33] & $580[0.1]$ & $450[30]$ & $635[0.5]$ & $455[29]$ & $635[1.2]$ \\
\hline 1c & 8.9 & $425[36]$ & $595[0.1]$ & $471[33]$ & $655[1.1]$ & $481[34]$ & $659[2.4]$ \\
\hline 1d & 8.8 & $400[35]$ & $595[1.8]$ & $465[30]$ & $690[2.0]$ & 481 [29] & $695[5.3]$ \\
\hline
\end{tabular}

Table 2. Photophysical properties of compounds $2 \mathrm{a}-\mathrm{d}$ at $\mathrm{pH} 7.4$ ( $\pm 40 \%$ Glycerol). Abbreviations are as follows: $\lambda_{\mathrm{abs}}$, wavelength of maximal absorption; $\lambda_{\mathrm{em}}$, wavelength of maximal emission; $\varepsilon$, molar absorption coefficient at $\lambda_{\text {abs }} \phi$, fluorescence quantum yield.

\begin{tabular}{|c|c|c|c|c|}
\hline & \multicolumn{2}{|c|}{ pH 7.4} & \multicolumn{2}{|c|}{ pH $7.4+40 \%$ Glycerol } \\
\hline & $\begin{array}{c}\lambda_{\text {abs }}[\varepsilon] \\
{[\mathrm{nm}]\left[\mathrm{mM}^{-1} \cdot \mathrm{cm}^{-1}\right]}\end{array}$ & $\begin{array}{c}\lambda_{\text {em }}[\phi] \\
{[n m][\%]}\end{array}$ & $\begin{array}{c}\lambda_{\mathrm{abs}}[\varepsilon] \\
{[\mathrm{nm}]\left[\mathrm{mM}^{-1} \cdot \mathrm{cm}^{-1}\right]}\end{array}$ & $\begin{array}{c}\lambda_{\mathrm{em}}[\phi] \\
{[\mathrm{nm}][\%]}\end{array}$ \\
\hline $2 a$ & $401[21]$ & $631[0.9]$ & 415 [19] & $630[1.7]$ \\
\hline $2 b$ & $461[32]$ & $667[0.7]$ & $474[34]$ & 669 [1.8] \\
\hline 2c & 461 [29] & $672[1.0]$ & $474[33]$ & $676[2.5]$ \\
\hline $2 d$ & $447[31]$ & 709 [1.0] & $470[30]$ & 709 [3.5] \\
\hline
\end{tabular}

various colours, we sought for red emitting fluorogenic chromophores (Figure 1a), which could display both fluorescence quantum yield increase and absorption red shift upon binding well-design complementary tags. We first targeted dyes with high potential of presenting fluorescence quantum yield increase upon motion restriction (Figure 1c). Second, to obtain binding-induced absorption red-shift, we sought for (i) dyes bearing an auxochromic group ionizable upon binding (altering thus fluorogen's photophysics), or (ii) negative solvatochromic dyes whose absorption could redshift within hydrophobic protein cavities (Figure 1c). Given the successful use of push-pull fluorogenic dyes in the design of fluorogen-based reporters ${ }^{10,15,19}$, we studied two series of fluorogen candidates composed of an electron-donating aromatic group (either 4-hydroxyphenyl or 4-dimethylaminophenyl) conjugated via two double bonds to heterocyclic acceptors of various electron-withdrawing strengths (Figure 1b). The extended $\pi$-electrons delocalization pathway allowed pushing the fluorescence of these donor-acceptor conjugated systems to the red edge of the visible spectrum. We evidenced their potential as fluorogens by a complete characterization of their photophysical properties (absorption and fluorescence emission) in conditions mimicking environment changes that might occur within biomolecule cavities such as immobilization, ionization or polarity drop. We further assayed their toxicity in mammalian cells, and evaluated their potential usability as fluorogenic probes by fluorescence microscopy.

\section{Results}

\section{Design and synthesis}

We recently reported the fluorogenic properties of HBR (4hydroxybenzylidene rhodanine $)^{19}$. HBR is composed of an electron-donating phenol moiety conjugated to an electronwithdrawing rhodanine head group. When deprotonated, HBR absorbs at $450 \mathrm{~nm}$ and emits around $545 \mathrm{~nm}^{19}$. This push-pull compound is related to the fluorogenic 4-hydroxybenzylidene5 -imidazolinone $(\mathrm{HBI})$ found in the green fluorescent protein $(G F P)^{20}$, in which the electron withdrawing head is an imidazolinone instead of a rhodanine. $\mathrm{HBI}$ is known to fluoresce only when immobilized in the GFP beta-barrel; the absence of fluorescence observed for the bare $\mathrm{HBI}$ in solution correlates with accessible radiationless decay channels along the cis-trans photoisomerization path.

To push the emission wavelength further to the red, we shifted absorption by extending the $\pi$-electron conjugation with an additional double bond between the donor and the acceptor. As the Stokes shift depends on the change of the dipole moment between the ground state and excited states, we also varied both the donor and the acceptor in order to extract structure-relationship trends. As donor, we examined (i) the 4-hydroxyphenyl, which can exist in a protonated and deprotonated state, the latter being more $\pi$-electron donor, and (ii) the 4-dimethylaminophenyl, a strong $\pi$-electron donor (Figure 1b). As acceptors, we tested the hydantoin (or 2,4imidazolidinedione), the thiohydantoin (or 2-thioxo-4imidazolidinone), the rhodanine (or 2-thioxo-4-thiazolidinone) and the methyl-pyridinium, in order to explore a palette of electron-withdrawing strengths (Figure 1b).

The push-pull compounds $\mathbf{1} \mathbf{a}-\mathbf{d}$ and $\mathbf{2 a - d}$ were obtained by condensation of the aldehydes $\mathbf{1}$ and $\mathbf{2}$ with either hydantoin $\mathbf{a}$, thiohydantoin $\mathbf{b}$, rhodanine $\mathbf{c}$ or methyl-pyridinium $\mathbf{d}$ in refluxing ethanol in presence of an appropriate amine base (Figure 2a, see Materials and Methods for details). The aldehyde $\mathbf{2}$ was commercially available. The aldehyde $\mathbf{1}$, on the other hand, was prepared by homologation of the 4-hydroxy- 

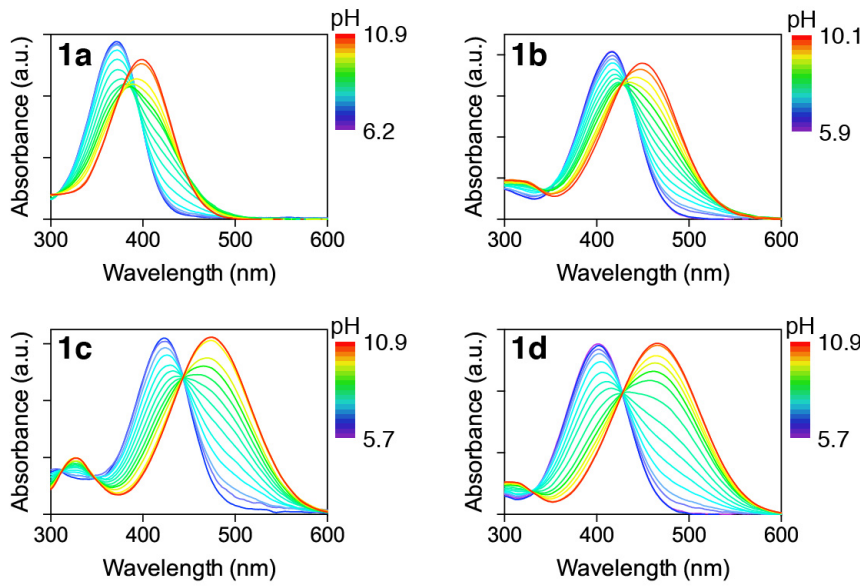

Figure 3. Absorption spectra of 1a-d at various $\mathrm{pH}$. The spectra were recorded in 0.01 $\mathrm{M}$ Britton-Robinson buffer ${ }^{23}$ at $25^{\circ} \mathrm{C}$. The evolution of absorption in function of $\mathrm{pH}$ allowed determining the acidity constant.

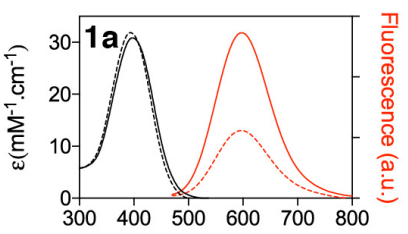

Wavelength $(\mathrm{nm})$

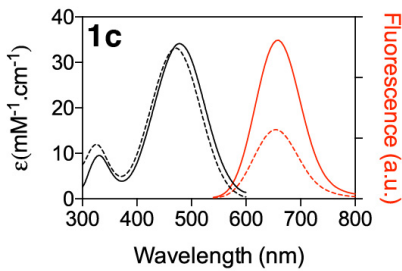

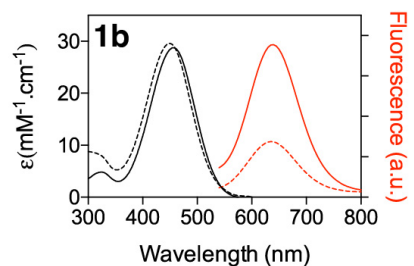

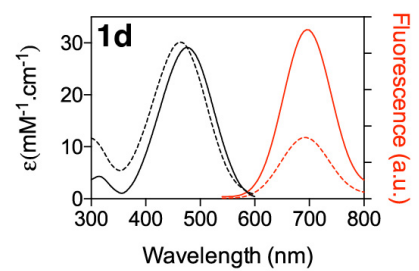

Figure 4. Absorption (black line) and emission (red line) spectra of 1a-d at $\mathbf{p H} 10$ in presence (solid line) or absence (dotted line) of $40 \%$ Glycerol. The spectra were recorded in $0.01 \mathrm{M}$ Britton-Robinson buffer ${ }^{23}$ at $25^{\circ} \mathrm{C}$.
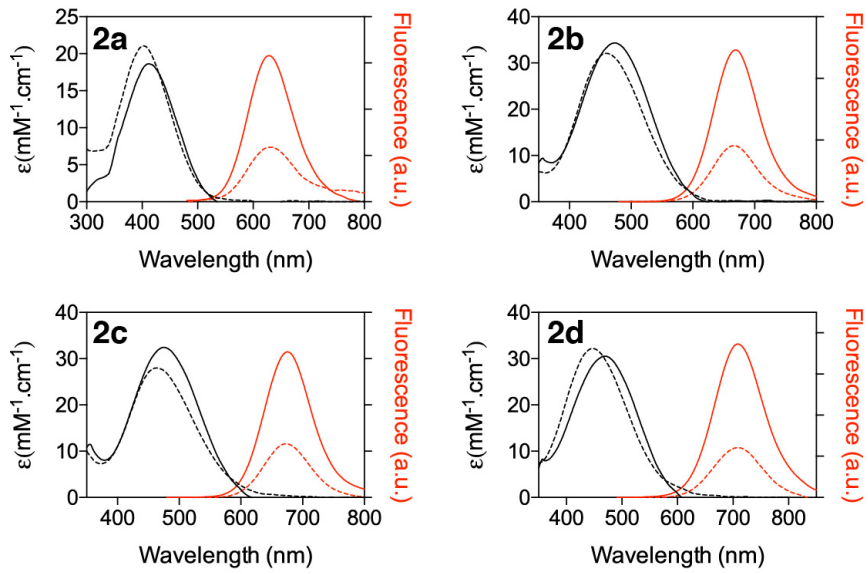

Figure 5. Absorption (black line) and emission (red line) spectra of $\mathbf{2 a - d}$ at pH 7.4 in presence (solid line) or absence (dotted line) of $40 \%$ Glycerol. The spectra were recorded in $0.01 \mathrm{M}$ Britton-Robinson buffer ${ }^{23}$ at $25^{\circ} \mathrm{C}$. benzaldehyde (Figure 2b). After efficient protection of the hydroxyl group with a methoxymethyl (MOM) acetal group, the protected 4-hydroxybenzaldehyde underwent a Wittig olefination with tributyl(1,3-dioxolan-2-ylmethyl) phosphonium bromide in presence of sodium hydride $(\mathrm{NaH})$ in tetrahydrofuran (THF). Final acidolysis of the Wittig product provided the aldehyde $\mathbf{1}$ with high yield.

\section{Absorption and emission properties}

Given that a phenolate is a better $\pi$-electron donor than a phenol, the protonated and deprotonated states of the compounds 1a-d exhibit different absorption properties (Figure 3 and Table 1). In aqueous solutions, the protonated states of $\mathbf{1 b}-\mathbf{d}$ absorb mainly violet light, while their deprotonated states absorb blue light (Figure 3 and Table 1). The absorption of $\mathbf{1 a}$ is blue-shifted compared to $\mathbf{1 b} \mathbf{b} \mathbf{d}$ (Figure 3 and Table 1). 1a absorbs mainly ultraviolet light when protonated and violet light when deprotonated. Deprotonation of $\mathbf{1 a}, \mathbf{1} \mathbf{b}, \mathbf{1} \mathbf{c}$ and $\mathbf{1 d}$ induces a red shift of about $20,35,55$ and $65 \mathrm{~nm}$, respectively. Spectrophotometric titrations showed that compounds $\mathbf{1 a - d}$ exhibit low acidity constant ( $\mathrm{p} K_{\mathrm{A}} \sim 8.8-8.9$ ) (Figure 3 and Table 1). Compounds 1ad are thus protonated at physiological pHs allowing to envision inducing an absorption red-shift - which can participate to fluorogen activation - by specific ionization within an engineered protein tag possessing a network of residues able to stabilized the negative charge (vide supra). Our photophysical study further showed that protonated 1a-d displayed high Stokes shift (150-200 nm) and fluoresced, albeit very weakly, between 520 and $590 \mathrm{~nm}$ (Table 1). Deprotonated 1a-d also exhibited high Stokes shift (180-230 $\mathrm{nm}$ ) and a palette of emission wavelengths in the orange/red, going from $590 \mathrm{~nm}$ (for 1a) to $690 \mathrm{~nm}$ (for 1d) (Table 1 and Figure 4). The high Stokes shifts of 1a-d open great prospects for multiplexed fluorescence observation using a single excitation wavelength.

Photophysical analysis of the series $\mathbf{2 a - d}$ in aqueous solution at $\mathrm{pH} 7.4$ showed that compounds $2 \mathrm{a}-\mathbf{d}$ absorb blue to violet light and fluoresced, albeit very weakly, in the red, with emission wavelengths going from $630 \mathrm{~nm}$ to $710 \mathrm{~nm}$ (Table 2 and Figure 5). Moreover, 2a-d exhibited ultra high Stokes shifts from 210 to $260 \mathrm{~nm}$. In order to see whether binding within biomolecules could change the absorption and emission of 2a-d because of polarity drop, we examined the effect of solvent polarity on their absorption and emission spectra. We observed that a drop in polarity led to a significant red shift in absorption and an important blue shift in emission (Figure 6). These observations enable to await strong chromatic modifications - both in absorption and emission upon specific interaction with complementary protein cavities of lower polarity.

Next, we asked if the fluorescence properties of $\mathbf{1 a - d}$ and $\mathbf{2 a - d}$ were sensitive to motion restriction. As mentioned above, compounds $\mathbf{1 a - d}$ and $\mathbf{2 a - d}$ barely fluoresce in aqueous 

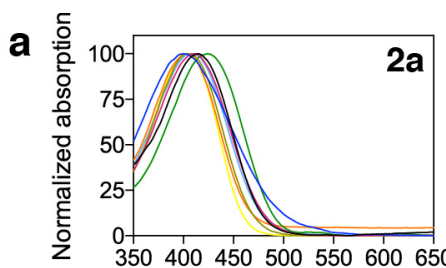

Wavelength $(\mathrm{nm})$

b
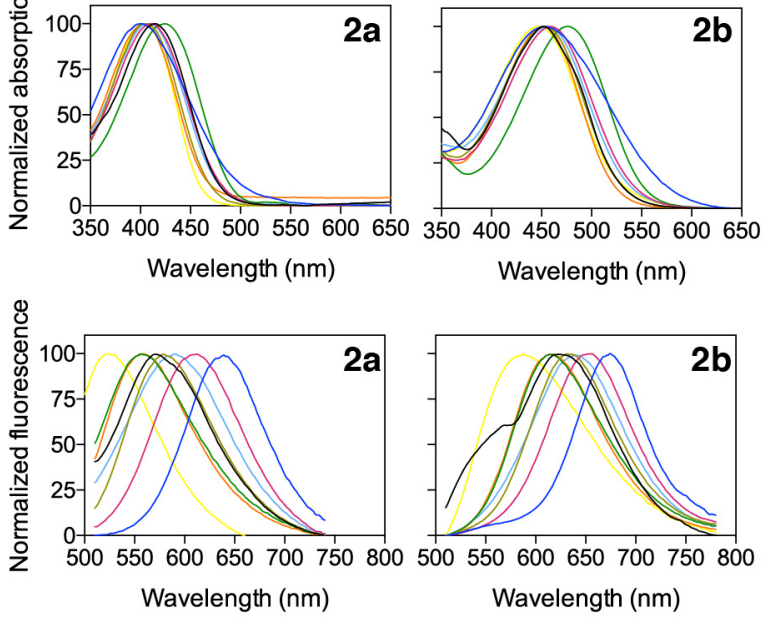

Wavelength $(\mathrm{nm})$

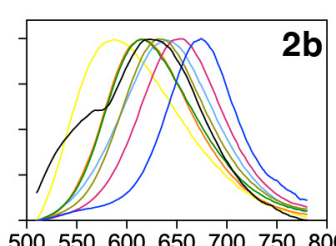

Wavelength $(\mathrm{nm})$
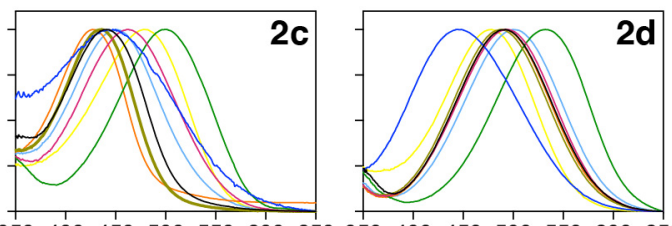

Wavelength $(\mathrm{nm})$

Wavelength $(\mathrm{nm})$

$$
\begin{array}{llll}
-\mathrm{H}_{2} \mathrm{O} & -\mathrm{EtOH} & -\mathrm{CHCl}_{3}-\mathrm{CH}_{3} \mathrm{CN} \\
-\mathrm{MeOH} & -\mathrm{DMSO} & -\mathrm{Acetone} & 1,4-\text { Dioxane }
\end{array}
$$

Figure 6. Solvato(fluo)chromic properties of $\mathbf{2 a - d}$. Normalized absorption (a) and emission (b) spectra of $\mathbf{2 a - d}$ in various solvents. The spectra were recorded at $25^{\circ} \mathrm{C}$.

a

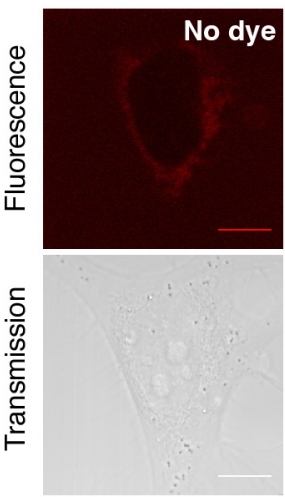

C
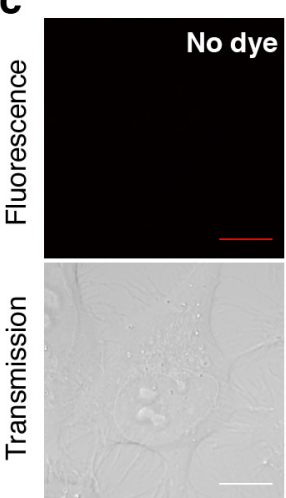
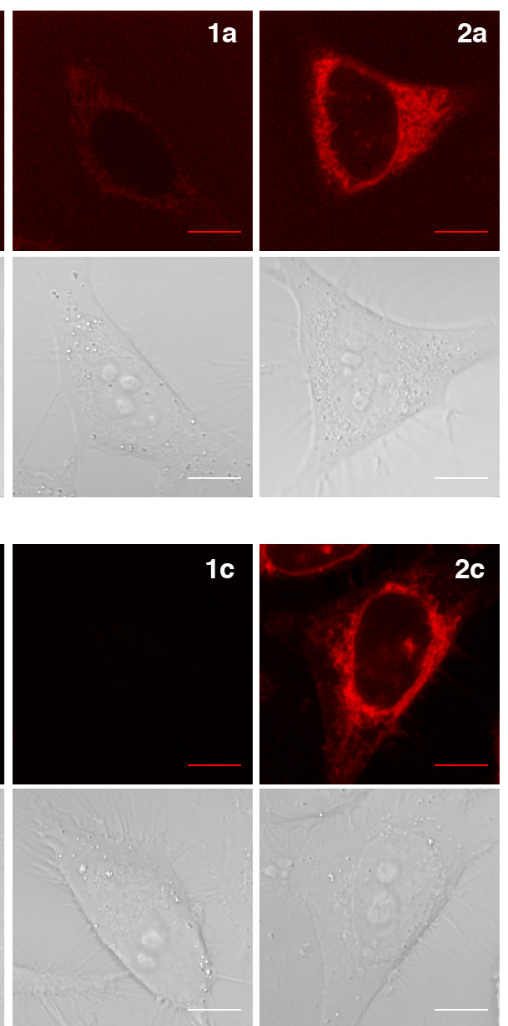
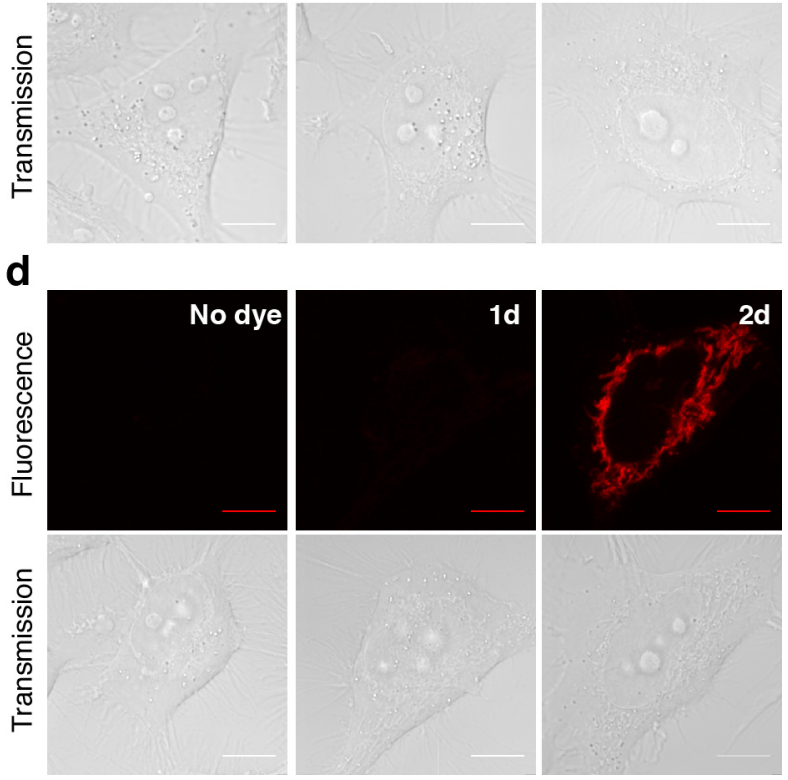

b

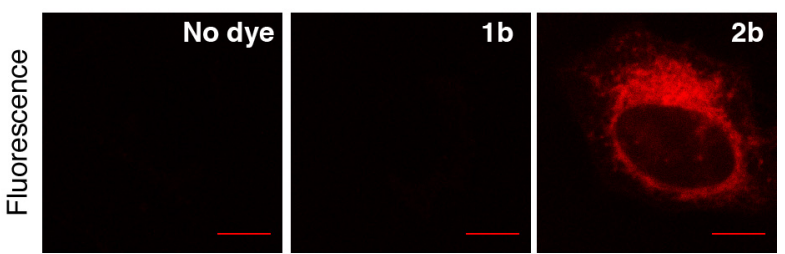

Figure 7. Cellular analysis. Confocal micrographs of HeLa cells incubated with $1 \mu \mathrm{M}$ of dye. (a-d) Side-by-side images were recorded using the same settings for direct comparison of the fluorescence intensities. (a) Ex/Em $405 \mathrm{~nm} / 454-797 \mathrm{~nm}$. (b-d) Ex/Em $488 \mathrm{~nm} / 493-797 \mathrm{~nm}$. Scale bars $10 \mu \mathrm{m}$.

solutions (see also fluorescence quantum yields reported in Tables 1 and 2). However, these compounds belong to the same family as $\mathrm{HBI}$ and $\mathrm{HBR} / \mathrm{HMBR}$, which are known to fluoresce only when immobilized in GFP and Y-FAST ${ }^{19}$ respectively. In the case of such fluorogens, the effect of motion restriction on fluorescence quantum yield can be evidenced easily by observing fluorescence enhancement in viscous solutions ${ }^{19}$. To evaluate whether $\mathbf{1 a - d}$ and $\mathbf{2 a - d}$ hold potential as fluorogens, we thus examined how the fluorescence quantum yield evolved upon solution viscosity increase. As viscous media, we used aqueous buffer complemented with $40 \%$ glycerol. This allowed us to obtain a 
buffer fourfold viscous than water ${ }^{21}$. The fluorescence quantum yields of compounds 1a-d (deprotonated) and 2a-d increased two- or three-fold in viscous medium (Tables 1 and 2, Figures 4 and 5). These results are in agreement and comparable with what we previously reported for the fluorogenic $\mathrm{HBR} / \mathrm{HMBR}^{19}$, enabling to anticipate large fluorescence exaltation upon immobilization within complementary protein cavities.

Table 3. Cellular toxicity of $\mathbf{1 a - d}$ and $\mathbf{2 a - d}$. HeLa cells were treated with media containing the fluorogenic dyes at various concentrations. Cell viability was tested after $5 \mathrm{~h}$ and $24 \mathrm{~h}$ of incubation. The table provides the degree of toxicity. No cell death (-): dead cells $<1 \%$, low cell death $(+)$ : $1 \%<$ dead cells $<20 \%$, significant cell death $(++)$ : dead cells $>50 \%$.

\begin{tabular}{|c|c|c|c|c|}
\hline & \multirow{2}{*}{$\begin{array}{l}\text { Cell death after } 5 \mathrm{~h} \\
10 \mu \mathrm{M}\end{array}$} & \multicolumn{3}{|c|}{ Cell death after $24 \mathrm{~h}$} \\
\hline & & $0.1 \mu \mathrm{M}$ & $1 \mu \mathrm{M}$ & $10 \mu \mathrm{M}$ \\
\hline $1 \mathrm{a}$ & - & - & - & + \\
\hline 1b & - & - & - & + \\
\hline 1c & - & - & - & - \\
\hline 1d & - & - & - & - \\
\hline $2 a$ & - & - & + & ++ \\
\hline $2 b$ & - & - & + & ++ \\
\hline 2c & - & - & - & - \\
\hline 2d & - & - & - & - \\
\hline
\end{tabular}

a

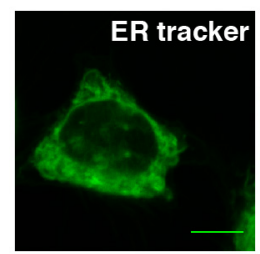

b

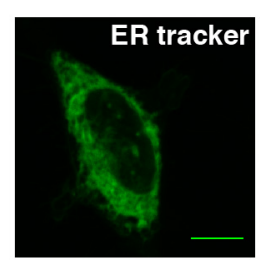

C

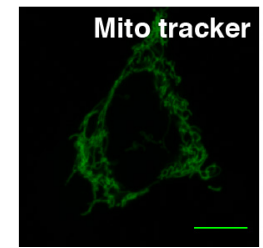

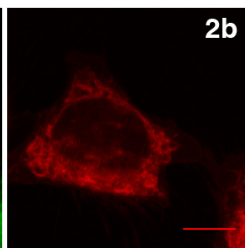
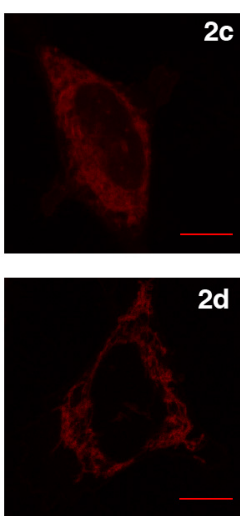

Figure 8. Co-localization studies. Confocal micrographs of HeLa cells co-incubated with $1 \mu \mathrm{M}$ of $\mathbf{2 b}$ (a), $\mathbf{2 c}$ (b), $\mathbf{2 d}$ (c) and either an ER tracker or a Mitochondrial tracker (Mito tracker). Imaging conditions: (a,b) ER tracker Ex/Em 405 nm/454-797 nm, 2b,c Ex/Em $488 \mathrm{~nm} / 493-797 \mathrm{~nm}$; (c) Mito tracker Ex/Em 543 nm/578-797 nm, 2d Ex/Em 458 $\mathrm{nm} / 465-593 \mathrm{~nm}$. Scale bars $10 \mu \mathrm{m}$.

\section{Cellular evaluation}

To be suitable for the design of fluorogen-based reporters, fluorogenic dyes must ideally exhibit no toxicity for cells and give no fluorescence background in cells in absence of their targets. We therefore examined the behaviour of $\mathbf{1 a - d}$ and $\mathbf{2 a -}$ d in mammalian cells, focusing on toxicity and non-specific fluorogen activation. The toxicity of $\mathbf{1 a - d}$ and $\mathbf{2 a - d}$ were evaluated in HeLa cells. Cells were treated with media containing the dyes and cell viability was determined after $5 \mathrm{~h}$ or $24 \mathrm{~h}$ (Table 3). We observed no cell death after $5 \mathrm{~h}$ of incubation with $10 \mu \mathrm{M}$ of dye, no matter the dye used. However, we observed detectable cell death after $24 \mathrm{~h}$ of incubation with high concentrations $(10 \mu \mathrm{M})$ of $\mathbf{2 a}$ and $\mathbf{2 b}$, and, in a much lesser extent, of $\mathbf{1 a}$ and $\mathbf{1 b}$ (Table $\mathbf{3}$ ). These results showed that our fluorogenic compounds did not exhibit significant toxicity in the micromolar or submicromolar range usually used for labeling fluorogen-activating tags.

We next asked by fluorescence microscopy if $\mathbf{1 a - d}$ and $\mathbf{2 a - d}$ underwent non-specific fluorescence activation in living mammalian cells. We treated HeLa cells with media containing $1 \mu \mathrm{M}$ dye. We observed two different trends. While compounds 1a-d exhibited no fluorescence background (Figure 7), compounds 2a-d did fluorescently label intracellular organelles or structures. Compounds $\mathbf{2 a}, \mathbf{2} \mathbf{b}$, and $\mathbf{2 c}$ specifically stained intracellular membranes (Figure 7). Colocalization studies showed that the fluorescently labelled structures were very likely membranes of the endoplasmic reticulum (ER) (Figure 8). Activation of 2a-c can result from immobilization within membranes. Compound $\mathbf{2 d}$, on the other hand, fluorescently labeled mitochondria (Figures 7 and 8), in accordance with previous studies reporting that pyridiniumcontaining compounds tend to accumulate in mitochondria because of their positive charge ${ }^{22}$. Our results demonstrated that only 1a-d were well-suited for designing new fluorogenbased reporters as they did not undergo, unlike 2a-d, any fluorescence activation in cells. However, even though 2a-d are not usable for the design of fluorogen-based reporters, they demonstrate that this series of dyes can undergo strong fluorogenic activation upon motion restriction. In addition, 2ad could find interesting applications as intracellular fluorogenic markers. Indeed, compared to commercially available mitochondrial or ER trackers, which requires long incubation time and washing steps, staining of mitochondria and the ER with $\mathbf{2 d}$ and $\mathbf{2 a - c}$ is straightforward and instantaneous.

\section{Discussion}

Fluorogenic dyes (so-called fluorogens) are chromophores that are non-fluorescent by their own but give strongly fluorescent complex when bound to a complementary receptor, allowing high contrast imaging. This behavior has been recently used to develop fluorogen-based reporters composed of genetically encodable protein tags that bind specifically fluorogenic dyes and activate their fluorescence ${ }^{4,5}$. Recently, a new concept of fluorogen-based reporters has been proposed with the development of Y-FAST (Yellow Fluorescence-Activating and absorption-Shifting Tag) ${ }^{19}$. Y-FAST's name highlights the two spectroscopic modifications used for fluorogen activation: upon binding, the fluorogen undergoes both an increase of the fluorescence quantum yield (because of motion restriction) and an absorption red shift (because of ionization of an auxochromic group). This second spectroscopic modification allows increasing the specificity of the fluorogen activation and thus the imaging contrast, as free or nonspecifically bound fluorogen does not contribute to the fluorescence signal. 
With the goal in mind of developing FluorescenceActivating and absorption-Shifting Tags (FASTs) emitting in the red, we studied two series of putative red fluorogenic dyes. The compounds $\mathbf{1 a - d}$ and $\mathbf{2 a - d}$ are push-pull compounds with an extended $\pi$-electron conjugation. They fluoresce, albeit very weakly, orange or red light in solution and possess high Stokes shifts, opening great prospects for multiplexed fluorescence observation using a single excitation wavelength. To be suitable for FASTs design, chromophores have to meet several criteria: (i) undergo fluorescence quantum yield exaltation upon motion restriction and (ii) hold potential for absorption red-shift upon binding. This latter property can arise either from ionization of an auxochromic group (as observed in the case of HBR and HMBR within Y-FAST) or from polarity change. The two series $\mathbf{1} \mathbf{a}-\mathbf{d}$ and $\mathbf{2 a - d}$ presented in this paper respond positively to these criteria. They all exhibit increase of fluorescence quantum yield upon motion restriction. Moreover, compounds $\mathbf{1}$ a-d are protonated at physiological pHs and undergo significant absorption red-shift upon deprotonation, holding thus great potential for absorption red shift upon interaction with engineered tags complementary to their deprotonated state. Compounds 2a-d do not have ionisable auxochromic group but they display negative solvatochromism, which could also be used to obtain absorption red shift upon binding engineered tags with lowpolarity cavities.

Within the overall process of designing fluorogen-based reporter, the protein engineering that follows fluorogen design is highly time-consuming and expensive. Therefore, choosing (and thus evaluating) correctly the fluorogen is essential. Among the criteria a fluorogen must fulfill, showing no toxicity and no fluorescence activation in cells are primordial. Our cell viability experiment enabled to determine the range of concentrations usable for each fluorogen, and will thus allow us to define upper values for reporter:fluorogen affinities. Our cellular evaluation further allowed us to determine that only 1a-d were suitable for designing new fluorogen-based reporters as they do not undergo, unlike $\mathbf{2 a - d}$, any significant fluorescence activation in cells. Although $\mathbf{2 a - d}$ are not ideal for the design of fluorogen-based reporters, their ability to specifically stain the endoplasmic reticulum and mitochondria could find applications in intracellular imaging.

\section{Conclusion}

In conclusion, we present in this paper the development and full characterization of new red fluorogenic dyes holding great potential for various applications in fluorescence bioimaging. The design of red-emitting fluorogen-based reporters through engineering of complementary activating protein tags is a current research direction of our laboratory. The framework/methodology used in this study is generic and should find general applicability in the discovery of new fluorogenic dyes suitable for the design of fluorogen-based reporters and biosensors.

\section{Acknowledgements}

This work has been supported by the Agence National de la Recherche (ANR-14-CE09-0002- 01), a PhD grant (C. L.) from Region Ile-de-France in the framework of DIM NanoK, PSL Research University (project IMRESOV), France Biolmaging and the Equipex Morphoscope 2.

\section{Materials and Methods}

\section{Chemical Synthesis}

General information Commercially available reagents were used as starting materials without further purification. NMR spectra were recorded on a $\mathrm{AC}$ Bruker spectrometer at 300 $\mathrm{MHz}$ for ${ }^{1} \mathrm{H}$ and $75 \mathrm{MHz}$ for ${ }^{13} \mathrm{C}$; chemical shifts are reported in ppm with protonated solvent as internal reference ${ }^{1} \mathrm{H}$, $\mathrm{CHD}_{2} \mathrm{COCD}_{3}$ in $\mathrm{CD}_{3} \mathrm{COCD}_{3} 2.05 \mathrm{ppm}, \mathrm{CHD}_{2} \mathrm{SOCD}_{3}$ in $\mathrm{CD}_{3} \mathrm{SOCD}_{3}$ $2.50 \mathrm{ppm} ;{ }^{13} \mathrm{C},{ }^{13} \mathrm{CD}_{3} \mathrm{COCD}_{3}$ in $\mathrm{CD}_{3} \mathrm{COCD}_{3} 29.84 \mathrm{ppm}$, ${ }^{13} \mathrm{CD}_{3} \mathrm{SOCD}_{3}$ in $\mathrm{CD}_{3} \mathrm{SOCD}_{3} 39.52 \mathrm{ppm}$; coupling constants $J$ are given in $\mathrm{Hz}$. Mass spectra (chemical ionization and electronic impact with $\mathrm{NH}_{3}$, or high resolution) were performed by the Service de Spectrométrie de Masse de Chimie ParisTech or the Institut de Chimie Organique et Analytique de I'Université d'Orléans. Column chromatography was performed on silica gel $60 \quad(0.040-0.063 \mathrm{~nm})$ Merck. Analytical thin-layer chromatography (TLC) was conducted on Merck silica gel 60 F254 precoated plates.

Synthesis of 4-(methoxymethoxy)benzaldehyde To a stirred solution of 4-hydroxybenzaldehyde $(610 \mathrm{mg}, 5.0 \mathrm{mmol})$ in anhydrous dichloromethane $(6 \mathrm{~mL})$ at $0{ }^{\circ} \mathrm{C}$ was added diisopropylethylamine (1292 $\mathrm{mg}, 10.0 \mathrm{mmol})$ and methoxymethyl chloride $(0.57 \mathrm{~mL}, 7.5 \mathrm{mmol})$. The mixture was stirred overnight at room temperature. The reaction was quenched with a saturated aqueous solution of ammonium chloride, and the aqueous layer was extracted with dichloromethane. The combined organic layers were washed with brine and dried over magnesium sulfate. After concentrating in vacuo, the residue was purified by flash chromatography on silica gel with cyclohexane/ethylacetate $(8 / 2, \quad v / v)$ to yield the desired 4-(methoxymethoxy) benzaldehyde (762 mg, 92\%) as a colorless oil. ${ }^{1} \mathrm{H}$ NMR (300 $\mathrm{MHz}, \mathrm{CD}_{3} \mathrm{COCD}_{3}, \delta$ in ppm): $9.92(\mathrm{~s}, 1 \mathrm{H}), 7.88(\mathrm{~d}, J=9.0 \mathrm{~Hz}, 2 \mathrm{H})$, $7.21(\mathrm{~d}, J=8.7 \mathrm{~Hz}, 2 \mathrm{H}), 5.33(\mathrm{~s}, 2 \mathrm{H}), 3.46(\mathrm{~s}, 3 \mathrm{H}) ;{ }^{13} \mathrm{C}$ NMR $(75$ $\mathrm{MHz}, \mathrm{CD}_{3} \mathrm{COCD}_{3}, \delta$ in ppm): 191.3, 163.1, 132.4(2C), 131.9, 117.2(2C), 94.9, 55.4 .

Synthesis of 4-hydroxycinnamaldehyde (1) To a stirred solution of sodium hydride (60\% dispersion in mineral oil) (360 $\mathrm{mg}, \quad 9.0 \mathrm{mmol}$ ) and tributyl (1,3-dioxolan-2-ylmethyl) phosphonium bromide $(3323 \mathrm{mg}, 9.0 \mathrm{mmol})$ in tetrahydrofurane $(20 \quad \mathrm{~mL})$ was added 4(methoxymethoxy)benzaldehyde $(748 \mathrm{mg}, 4.5 \mathrm{mmol})$. The solution was stirred overnight at room temperature in the presence of a catalytic amount of 18-crown-6. After addition of water, the reaction mixture was extracted with dichloromethane and the combined organic layers were 
washed with brine. The residue concentrated in vacuo was dissolved in tetrahydrofuran $(10 \mathrm{~mL})$. An aqueous solution of hydrochloric acid was added and the solution was stirred until complete hydrolysis. The reaction mixture was extracted with dichloromethane and the combined organic layers were washed with brine and dried over magnesium sulfate. After concentrating in vacuo, the residue was purified by flash chromatography on silica gel with cyclohexane/ethylacetate $(8 / 2, v / v)$ to yield the desired 4-hydroxycinnamaldehyde 1 (526 $\mathrm{mg}, 79 \%)$ as a yellow flocculent solid. ${ }^{1} \mathrm{H}$ NMR $(300 \mathrm{MHz}$, $\mathrm{CD}_{3} \mathrm{COCD}_{3}, \delta$ in ppm): $9.64(\mathrm{~d}, J=7.8 \mathrm{~Hz}, 1 \mathrm{H}), 9.04(\mathrm{~s}, 1 \mathrm{H}), 7.60$ $(\mathrm{m}, 3 \mathrm{H}), 6.94(\mathrm{~d}, J=8.7 \mathrm{~Hz}, 2 \mathrm{H}), 6.61$ (dd, $J=7.8,15.9 \mathrm{~Hz} 1 \mathrm{H})$; ${ }^{13} \mathrm{C}$ NMR $\left(75 \mathrm{MHz}, \mathrm{CD}_{3} \mathrm{SOCD}_{3}, \delta\right.$ in ppm): 193.9, 161.3, 153.7, 131.6 (2C), 127.0, 126.8, 116.9 (2C); $\mathrm{MS}\left(\mathrm{Cl}, \mathrm{NH}_{3}\right): \mathrm{m} / \mathrm{z} 149.07$ $[\mathrm{M}+\mathrm{H}]^{+}$, calcd mass for $\left[\mathrm{C}_{9} \mathrm{H}_{9} \mathrm{O}_{2}\right]^{+}:$149.06; HRMS (ESI): $\mathrm{m} / \mathrm{z}$ 149.0598 $[\mathrm{M}+\mathrm{H}]^{+}$, calcd mass for $\left[\mathrm{C}_{9} \mathrm{H}_{9} \mathrm{O}_{2}\right]^{+}: 149.0603$.

\section{General protocol for the synthesis of $1 \mathrm{a}-\mathrm{d}$ and $\mathbf{2 a - d}$}

To a stirred solution of aldehyde (1 or 2; $1 \mathrm{mmol}$ ) and heterocycle ( $a$ or $b$ or $c$ or $d ; 1 \mathrm{mmol}$ ) in ethanol $(10 \mathrm{~mL}$ ) was added the amine base $(0.09 \mathrm{~mL}$ of 2 -aminoethanol for $1 \mathrm{a}, 1 \mathrm{~b}$, 1d, 2a; $12 \mathrm{mg}$ of 4-(4methylamino)-pyridine for 1c, 2b, 2c; 2 drops of piperidine for $2 \mathrm{~d}$ ). The solution was stirred at reflux for $20 \mathrm{~h}$. After cooling to $4{ }^{\circ} \mathrm{C}$, the precipitate was filtered and the crude solid was washed with water and then with ethanol to give the desired product.

(Z)-5-((E)-3-(4-hydroxyphenyl)allylidene)imidazolidine-2,4dione (1a) Yellow powder (6\%). ${ }^{1} \mathrm{H}$ NMR $\left(300 \mathrm{MHz}, \mathrm{CD}_{3} \mathrm{SOCD}_{3}\right.$, $\delta$ in ppm): $10.95(\mathrm{~s}, 1 \mathrm{H}), 10.56(\mathrm{~s}, 1 \mathrm{H}), 9.87(\mathrm{~s}, 1 \mathrm{H}), 7.34(\mathrm{~d}, J=$ $8.7 \mathrm{~Hz}, 2 \mathrm{H}), 7.06(\mathrm{dd}, J=11.7,15.3 \mathrm{~Hz}, 1 \mathrm{H}), 6.81(\mathrm{~m}, 3 \mathrm{H}), 6.221$ (d, $J=12 \mathrm{~Hz}, 1 \mathrm{H}) ;{ }^{13} \mathrm{C} \mathrm{NMR}\left(75 \mathrm{MHz}, \mathrm{CD}_{3} \mathrm{SOCD}_{3}, \delta\right.$ in ppm): $164.7,158.2,154.5,137.2,128.3(2 \mathrm{C}), 128.2,127.9,119.3$, 115.8(2C), 109.8; MS (ESI): $\mathrm{m} / \mathrm{z} 229.2[\mathrm{M}-\mathrm{H}]$, calcd mass for $\left[\mathrm{C}_{12} \mathrm{H}_{9} \mathrm{~N}_{2} \mathrm{O}_{3}\right]^{-}:$229.1; HRMS (ESI): $\mathrm{m} / \mathrm{z} 231.0762[\mathrm{M}+\mathrm{H}]^{+}$, calcd mass for $\left[\mathrm{C}_{12} \mathrm{H}_{11} \mathrm{~N}_{2} \mathrm{O}_{3}\right]^{+}: 231.0770$.

\section{(Z)-5-((E)-3-(4-hydroxyphenyl)allylidene)-2-}

thioxoimidazolidin-4-one (1b) Orange red solid (22\%). ${ }^{1} \mathrm{H}$ NMR (300 MHz, $\mathrm{CD}_{3} \mathrm{SOCD}_{3}, \delta$ in ppm): $12.17(\mathrm{~s}, 2 \mathrm{H}), 9.95(\mathrm{~s}, 1 \mathrm{H})$, $7.40(\mathrm{~d}, J=8.4,2 \mathrm{H}), 7.32(\mathrm{dd}, J=12.0,15.3 \mathrm{~Hz}, 1 \mathrm{H}), 6.99(\mathrm{~d}, J=$ $15.3,1 \mathrm{H}), 6.79(\mathrm{~d}, J=8.4,2 \mathrm{H}), 6.34(\mathrm{~d}, J=12.0 \mathrm{~Hz}, 1 \mathrm{H}) ;{ }^{13} \mathrm{C}$ NMR (75 MHz, $\mathrm{CD}_{3} \mathrm{SOCD}_{3}, \delta$ in ppm): 176.2, 164.8, 158.7, 140.0, 128.9 (2C), 128.1, 127.8, 119.4, 115.9 (2C), 113.4; MS (ESI): $\mathrm{m} / \mathrm{z} 245.3[\mathrm{M}-\mathrm{H}]^{+}$, calcd mass for $\left[\mathrm{C}_{12} \mathrm{H}_{9} \mathrm{~N}_{2} \mathrm{O}_{2} \mathrm{~S}\right]^{-}:$245.0; HRMS (ESI): $\mathrm{m} / \mathrm{z} 247.0540[\mathrm{M}+\mathrm{H}]^{+}$, calcd mass for $\left[\mathrm{C}_{12} \mathrm{H}_{11} \mathrm{~N}_{2} \mathrm{O}_{2} \mathrm{~S}\right]^{+}: 247.0541$.

(Z)-5-((E)-3-(4-hydroxyphenyl)allylidene)-2-thioxothiazolidin4-one (1c) Orange solid (46\%). ${ }^{1} \mathrm{H} \mathrm{NMR}\left(300 \mathrm{MHz}, \mathrm{CD}_{3} \mathrm{SOCD}_{3}, \delta\right.$ in ppm): $13.45(\mathrm{~s}, 1 \mathrm{H}), 7.51(\mathrm{~d}, J=9.0 \mathrm{~Hz}, 2 \mathrm{H}), 7.32(\mathrm{~d}, J=11.4$ $\mathrm{Hz}, 1 \mathrm{H}), 7.22(\mathrm{~d}, J=15.0 \mathrm{~Hz}, 1 \mathrm{H}), 6.68(\mathrm{~m}, 3 \mathrm{H}) ;{ }^{13} \mathrm{C}$ NMR $(75$ $\mathrm{MHz}, \mathrm{CD}_{3} \mathrm{SOCD}_{3}, \delta$ in ppm): 195.1, 168.7, 159.7, 145.6, 133.2, 130.2(2C), 126.9, 124.6, 120.5, 116.0(2C); $\mathrm{MS}\left(\mathrm{Cl}, \mathrm{NH}_{3}\right): \mathrm{m} / \mathrm{z}$ 264.08 $[\mathrm{M}+\mathrm{H}]^{+}$, calcd mass for $\left[\mathrm{C}_{12} \mathrm{H}_{10} \mathrm{NO}_{2} \mathrm{~S}_{2}\right]^{+}:$264.02; HRMS (ESI): $\mathrm{m} / \mathrm{z} 264.0149[\mathrm{M}+\mathrm{H}]^{+}$, calcd mass for $\left[\mathrm{C}_{12} \mathrm{H}_{10} \mathrm{NO}_{2} \mathrm{~S}_{2}\right]^{+}$: 264.0153 .
4-((1E,3E)-4-(4-hydroxyphenyl)buta-1,3-dien-1-yl)-1methylpyridin-1-ium iodide (1d) Brown solid (21\%). ${ }^{1} \mathrm{H}$ NMR (300 MHz, $\mathrm{CD}_{3} \mathrm{SOCD}_{3}, \delta$ in ppm): $8.72(\mathrm{~d}, J=6.6 \mathrm{~Hz}, 2 \mathrm{H}$ ), 8.05 (d, $J=6.9 \mathrm{~Hz}, 2 \mathrm{H}$ ), 7.78 (ddd, $J=15.6,7.5 \mathrm{~Hz}, 2.4 \mathrm{~Hz} 1 \mathrm{H}$ ), 7.46 $(\mathrm{d}, J=8.7 \mathrm{~Hz}, 2 \mathrm{H}), 7.03(\mathrm{~m}, 2 \mathrm{H}), 6.78(\mathrm{~m}, 3 \mathrm{H}), 4.19(\mathrm{~s}, 3 \mathrm{H}) ;{ }^{13} \mathrm{C}$ NMR (75 MHz, $\mathrm{CD}_{3} \mathrm{SOCD}_{3}, \delta$ in ppm): 159.4, 152.6, 144.7 (2C), $142.7,141.2,129.4$ (2C), 127.0, 124.8, 124.6, 122.8 (2C), 116.0 (2C), 46.7; $\mathrm{MS}$ (ESI): $\mathrm{m} / \mathrm{z} 238.2\left[\mathrm{M}^{\prime}\right]^{+}$, calcd mass for $\left[\mathrm{C}_{16} \mathrm{H}_{16} \mathrm{NO}\right]^{+}:$238.1; HRMS (ESI): $\mathrm{m} / \mathrm{z} 238.1228$ [M'] $^{+}$, calcd mass for $\left[\mathrm{C}_{16} \mathrm{H}_{16} \mathrm{NO}\right]^{+}: 238.1226$.

\section{(Z)-5-((E)-3-(4-(dimethylamino)phenyl)allylidene)}

imidazolidine-2,4-dione (2a) Red powder (42\%). ${ }^{1} \mathrm{H}$ NMR (300 $\mathrm{MHz}, \mathrm{CD}_{3} \mathrm{SOCD}_{3}, \delta$ in ppm): $10.70(\mathrm{~s}, 2 \mathrm{H}), 7.35(\mathrm{~d}, J=8.7 \mathrm{~Hz}$, $2 \mathrm{H}), 7.01$ (dd, $J=11.7,15.3 \mathrm{~Hz}, 1 \mathrm{H}), 6.80(\mathrm{~d}, J=15.3 \mathrm{~Hz}, 1 \mathrm{H})$, $6.72(\mathrm{~d}, J=8.7 \mathrm{~Hz}, 2 \mathrm{H}), 6.22(\mathrm{~d}, J=11.7 \mathrm{~Hz}, 1 \mathrm{H}), 2.95(\mathrm{~s}, 6 \mathrm{H})$; ${ }^{13} \mathrm{C} \mathrm{NMR}\left(75 \mathrm{MHz}, \mathrm{CD}_{3} \mathrm{SOCD}_{3}, \delta\right.$ in ppm): 164.8, 154.6, 150.5, $137.8,128.1(2 \mathrm{C}), 127.4,124.5,117.6,112.4(2 \mathrm{C}), 110.5$, 39.8(2C); $\mathrm{MS}\left(\mathrm{Cl}, \mathrm{NH}_{3}\right): \mathrm{m} / \mathrm{z} 258.17[\mathrm{M}+\mathrm{H}]^{+}$, calcd mass for $\left[\mathrm{C}_{14} \mathrm{H}_{16} \mathrm{~N}_{3} \mathrm{O}_{2}\right]^{+}:$258.12; HRMS (ESI): $\mathrm{m} / \mathrm{z} 258.1249[\mathrm{M}+\mathrm{H}]^{+}$, calcd mass for $\left[\mathrm{C}_{14} \mathrm{H}_{16} \mathrm{~N}_{3} \mathrm{O}_{2}\right]^{+}: 258.1243$.

\section{(Z)-5-((E)-3-(4-(dimethylamino)phenyl)allylidene)-2-} thioxoimidazolidin-4-one (2b) Dark powder (55\%). ${ }^{1} \mathrm{H}$ NMR (300 MHz, $\mathrm{CD}_{3} \mathrm{SOCD}_{3}, \delta$ in ppm): $12.18(\mathrm{~s}, 1 \mathrm{H}), 12.07$ (s, $\left.1 \mathrm{H}\right)$, $7.40(\mathrm{~d}, J=8.4 \mathrm{~Hz}, 2 \mathrm{H}), 7.26(\mathrm{~m}, 1 \mathrm{H}), 6.97(\mathrm{~d}, J=15.0 \mathrm{~Hz}, 1 \mathrm{H})$, $6.73(\mathrm{~d}, J=8.4 \mathrm{~Hz}, 2 \mathrm{H}), 6.35(\mathrm{~d}, J=11.7 \mathrm{~Hz}, 1 \mathrm{H}), 2.97(\mathrm{~s}, 6 \mathrm{H}) .{ }^{13} \mathrm{C}$ NMR $\left(75 \mathrm{MHz}, \mathrm{CD}_{3} \mathrm{SOCD}_{3}, \delta\right.$ in ppm): 175.5, 164.7, 150.9, $141.0,128.7(2 \mathrm{C}), 127.0,124.3,117.6,114.4,112.1(2 \mathrm{C})$, $39.8(2 \mathrm{C}) ; \mathrm{MS}\left(\mathrm{Cl}, \mathrm{NH}_{3}\right): \mathrm{m} / \mathrm{z} 274.13[\mathrm{M}+\mathrm{H}]^{+}$, calcd mass for $\left[\mathrm{C}_{14} \mathrm{H}_{16} \mathrm{~N}_{3} \mathrm{OS}\right]^{+}:$:274.10; HRMS (ESI): $\mathrm{m} / \mathrm{z} 274.1009[\mathrm{M}+\mathrm{H}]^{+}$, calcd mass for $\left[\mathrm{C}_{14} \mathrm{H}_{16} \mathrm{~N}_{3} \mathrm{OS}\right]^{+}: 274.1014$.

\section{(Z)-5-((E)-3-(4-(dimethylamino)phenyl)allylidene)-2-}

thioxothiazolidin-4-one (2c) Dark powder (42\%). ${ }^{1} \mathrm{H}$ NMR (300 $\mathrm{MHz}, \mathrm{CD}_{3} \mathrm{SOCD}_{3}, \delta$ in ppm): $13.45(\mathrm{~s}, 1 \mathrm{H}), 7.51(\mathrm{~d}, J=9.0 \mathrm{~Hz}$, $2 \mathrm{H}), 7.32(\mathrm{~d}, J=11.4 \mathrm{~Hz}, 1 \mathrm{H}), 7.22(\mathrm{~d}, J=15.0 \mathrm{~Hz}, 1 \mathrm{H}), 6.68(\mathrm{~m}$, $3 \mathrm{H}), 2.99(\mathrm{~s}, 6 \mathrm{H}) ;{ }^{13} \mathrm{C}$ NMR $\left(75 \mathrm{MHz}, \mathrm{CD}_{3} \mathrm{SOCD}_{3}, \delta\right.$ in ppm): $194.7,168.6,151.6,146.6,133.9,130.0(2 \mathrm{C}), 123.1,122.3$, 118.3, 111.9(2C), 39.7(2C); $\mathrm{MS}\left(\mathrm{Cl}, \mathrm{NH}_{3}\right): \mathrm{m} / \mathrm{z} 291.10[\mathrm{M}+\mathrm{H}]^{+}$, calcd mass for $\left[\mathrm{C}_{14} \mathrm{H}_{15} \mathrm{~N}_{2} \mathrm{OS}_{2}\right]^{+}:$291.06; HRMS (ESI): $\mathrm{m} / \mathrm{z}$ $291.0623[\mathrm{M}+\mathrm{H}]^{+}$, calcd mass for $\left[\mathrm{C}_{14} \mathrm{H}_{15} \mathrm{~N}_{2} \mathrm{OS}_{2}\right]^{+}: 291.0626$.

4-((1E,3E)-4-(4-(dimethylamino)phenyl)buta-1,3-dien-1-yl)-1methylpyridin-1-ium iodide (2d) Dark powder (41\%). ${ }^{1} \mathrm{H}$ NMR (300 MHz, $\mathrm{CD}_{3} \mathrm{SOCD}_{3}, \delta$ in ppm): $8.69(\mathrm{~d}, J=6.8 \mathrm{~Hz}, 2 \mathrm{H}), 8.02$ $(\mathrm{d}, J=6.9 \mathrm{~Hz}, 2 \mathrm{H}), 7.79(\mathrm{dt}, J=15.4,5.0 \mathrm{~Hz}, 1 \mathrm{H}), 7.47(\mathrm{~d}, J=8.8$ $\mathrm{Hz}, 2 \mathrm{H}), 7.01(\mathrm{~d}, J=5.1 \mathrm{~Hz}, 2 \mathrm{H}), 6.72(\mathrm{~m}, 3 \mathrm{H}), 4.18(\mathrm{~s}, 3 \mathrm{H}), 2.98$ $(\mathrm{s}, 6 \mathrm{H}) ;{ }^{13} \mathrm{C} \mathrm{NMR}\left(75 \mathrm{MHz}, \mathrm{CD}_{3} \mathrm{SOCD}_{3}, \delta\right.$ in ppm): 152.7, 151.1, 144.5 (2C), 143.2, 142.0, 129.1(2C), 123.5, 123.3, 123.1, 122.4(2C), 112.0(2C), 46.5, 39.8(2C); MS (ESI): m/z $265.2\left[\mathrm{M}^{\prime}\right]^{+}$, calcd mass for $\left[\mathrm{C}_{18} \mathrm{H}_{21} \mathrm{~N}_{2}\right]^{+}:$265.2; HRMS (ESI): $\mathrm{m} / \mathrm{z} 265.1696$ $\left[\mathrm{M}^{\prime}\right]^{+}$, calcd mass for $\left[\mathrm{C}_{18} \mathrm{H}_{21} \mathrm{~N}_{2}\right]^{+}:$265.1699. 


\section{Physico-chemical experiments}

$\mathrm{pH}$ measurements were performed on a standard $\mathrm{pH}$ meter PHM210 Radiometer Analytical (calibrated with aqueous buffers at $\mathrm{pH} 4$ and 7 or 10) with a Crison 5208 Electrode (Barcelona, Spain). UV/Vis absorption spectra were recorded in $1 \mathrm{~cm} \times 1 \mathrm{~cm}$ quartz cuvettes (Hellma) on a diode array UV/Vis spectrophotometer (Evolution array, Thermo Scientific). Corrected fluorescence spectra upon one-photon excitation were recorded with a Photon Technology International QuantaMaster QM-1 spectrofluorimeter (PTI, Monmouth Junction, NJ) equipped with a Peltier cell holder (TLC50, Quantum Northwest, Shoreline, WA). The overall emission quantum yields after one-photon excitation $\phi$ were determined as previously described ${ }^{19}$.

\section{Fluorescence Microscopy}

Confocal micrographs were acquired on a Zeiss LSM 710 Laser Scanning Microscope equipped with a Plan Apochromat $63 \times$ / 1.4 NA oil immersion objective. ZEN software was used to collect the data. Images were analyzed with Image J.

\section{Mammalian Cell Culture}

HeLa cells were cultured in DMEM supplemented with phenol red, Glutamax I, $10 \%$ (vol/vol) fetal calf serum (FCS), and $1 \%$ penicillin-streptomycin at $37{ }^{\circ} \mathrm{C}$ within a $5 \% \mathrm{CO}_{2}$ atmosphere. For microscopic imaging, cells were seeded in $\mu$ Slide IBIDI (Biovalley) coated with poly-L-lysine. Cells were washed with PBS, incubated in DMEM (without phenol red) complemented with $1 \mathrm{a}-\mathrm{d}$ and $2 \mathrm{a}-\mathrm{d}$ at the indicated concentration, and imaged directly without washing. For the co-localization study, HeLa cells were prestained with ER-Tracker ${ }^{\text {TM }}$ Blue-White DPX (Molecular Probes, Life Technologies) or MitoTracker ${ }^{\oplus}$ Red CMXRos (Molecular Probes, Life Technologies) following the manufacturer's protocol.

\section{Toxicity cellular assay}

HeLa cells were incubated with $1 a-d$ and $2 a-d$ solutions at the indicated concentrations for various durations. Cell viability was assayed by fluorescence microscopy using the LIVE/DEAD ${ }^{\circ}$ viability/cytotoxicity assay kit (Molecular Probes, Life Technologies) following the manufacturer's protocol.

\section{References}

1 H. O'Hare, K. Johnsson and A. Gautier, Curr. Opin. Struct. Biol., 2007, 17, 488-494.

2 M. J. Hinner and K. Johnsson, Curr. Opin. Biotechnol., 2010, 21, 766-776.

3 K. M. Dean and A. E. Palmer, Nat. Chem. Biol., 2014, 10, 512523.

4 M. P. Bruchez, Curr. Opin. Chem. Biol., 2015, 27, 18-23.

5 L. Jullien and A. Gautier, Methods Appl. Fluoresc., 2015, 3, 042007.

6 C. Szent-Gyorgyi, B. A. Schmidt, Y. Creeger, G. W. Fisher, K. L. Zakel, S. Adler, J. A. J. Fitzpatrick, C. A. Woolford, Q. Yan, K. V. Vasilev, P. B. Berget, M. P. Bruchez, J. W. Jarvik and A. Waggoner, Nat. Biotechnol., 2008, 26, 235-240.
7 S. L. Schwartz, Q. Yan, C. A. Telmer, K. A. Lidke, M. P. Bruchez and D. S. Lidke, ACS Chem. Biol., 2015, 10, 539-546.

8 C. A. Telmer, R. Verma, H. Teng, S. Andreko, L. Law and M. P. Bruchez, ACS Chem. Biol., 2015, 10, 1239-1246.

9 H. Ozhalici-Unal, C. L. Pow, S. A. Marks, L. D. Jesper, G. L. Silva, N. I. Shank, E. W. Jones, J. M. Burnette, P. B. Berget and B. A. Armitage, J. Am. Chem. Soc. 2008, 130, 12620-12621.

10 J. S. Paige, K. Y. Wu and S. R. Jaffrey, Science, 2011, 333, 642646.

11 R. L. Strack, M. D. Disney and S. R. Jaffrey, Nat. Meth., 2013, 10, 1219-1224.

12 P. Wang, J. Querard, S. Maurin, S. S. Nath, T. Le Saux, A. Gautier and L. Jullien, Chem. Sci., 2013, 4, 2865-2873.

13 K. Y. Han, B. J. Leslie, J. Fei, J. Zhang and T. Ha, J. Am. Chem. Soc. 2013, 135, 19033-19038.

14 W. Song, R. L. Strack, N. Svensen and S. R. Jaffrey, J. Am. Chem. Soc., 2014, 136, 1198-1201.

15 I. Yapici, K. S. S. Lee, T. Berbasova, M. Nosrati, X. Jia, C. Vasileiou, W. Wang, E. M. Santos, J. H. Geiger and B. Borhan, J. Am. Chem. Soc., 2015, 137, 1073-1080.

16 Y. Hori, T. Norinobu, M. Sato, K. Arita, M. Shirakawa and K. Kikuchi, J. Am. Chem. Soc., 2013, 135, 12360-12365.

17 G. Lukinavicius, K. Umezawa, N. Olivier, A. Honigmann, G. Yang, T. Plass, V. Mueller, L. Reymond, I. R. Corrêa Jr, Z.-G. Luo, C. Schultz, E. A. Lemke, P. Heppenstall, C. Eggeling, S. Manley and K. Johnsson, Nat. Chem., 2013, 5, 132-139.

18 G. Lukinavicius, L. Reymond, E. D'Este, A. Masharina, F. Göttfert, H. Ta, A. Güther, M. Fournier, S. Rizzo, H. Waldmann, C. Blaukopf, C. Sommer, D. W. Gerlich, H.-D. Arndt, S. W. Hell and K. Johnsson, Nat. Meth. 2014, 11, 731733.

19 M.-A. Plamont, E. Billon-Denis, S. Maurin, C. Gauron, F. M. Pimenta, C. G. Specht, J. Shi, J. Querard, B. Pan, J. Rossignol, K. Moncoq, N. Morellet, M. Volovitch, E. Lescop, Y. Chen, A. Triller, S. Vriz, T. Le Saux, L. Jullien and A. Gautier, Proc. Natl. Acad. Sci. USA, 2016, 113, 497-502.

20 R. Y. Tsien, Annu. Rev. Biochem., 1998, 67, 509-544.

21 N.-S. Cheng, Ind. Eng. Chem. Res., 2008, 47, 3285-3288.

22 G. R. G. Rosania, J. W. J. Lee, L. L. Ding, H.-S. H. Yoon and Y.T. Y. Chang, J. Am. Chem. Soc., 2003, 125, 1130-1131.

23 J. A. Coch-Frugoni, Gazz. Chem. Ital., 1957, 87, 403-407. 